Reviews

\title{
Indigenous Mestizos: The Politics of Race and Culture in Cuzco, Peru, 1919-1991. by Marisol de la Cadena. Durham, NC: Duke University Press (2000), xiii, 408 pp.
}

\section{Reviewed by Sarah England, Department of Anthropology, University of California, Davis.}

In the past two decades scholars and activists have increasingly come to question hegemonic national ideologies that claim there is no racism in Latin America. While it has long been acknowledged that there are serious social cleavages in Latin American societies, these were analyzed primarily as the result of cultural discrimination and class stratification rather than persistent racism. This ideological feat was accomplished largely through the work of Latin American elite intellectuals and North American anthropologists who argued that because Latin Americans do not understand social groups as constituted by a set of strictly biological and immutable traits, but rather by cultural attributes and social conditions, then their thinking and forms of discrimination were not racist in the same sense that race and racism operated in North America and Europe. In Indigenous Mestizos, Marisol de la Cadena makes an excellent contribution to a burgeoning literature that is working to deconstruct this prevailing view and illustrate the many subtle (and not so subtle) ways that racism and race-thinking continue to shape social groups, hierarchies, and personal identities in Latin America. De la Cadena draws on recent literature by European scholars (Paul Gilroy, Etienne Balibar, and Verena Stolcke) who argue that though current forms of cultural discrimination and xenophobia in Europe and North America elide references to biological concepts of race, their ideological underpinnings and social consequences still constitute a form of "racism without race." De la Cadena argues that though this form of race-thinking may be new to Europe, it is not at all new to Latin America. Her book is dedicated to explaining the intellectual origins of this version of "racism without race" in Peru starting in the 1920s, and illustrating how it has been both appropriated and redefined among working class peoples in Cuzco.

Like many other studies of race in Latin America, a large portion of Indigenous Mestizos is dedicated to explaining the elite intellectual origins of the ideologies of mestizaje and indigenismo, the latter of which would eventually become official state ideology in Peru, guiding the formulation of cultural, educational, social, and even political policies. These twin ideologies, found in various forms throughout Latin America, valorize miscegenation and indigenous heritage in the face of North American and European beliefs of the early 1900s that the relative "underdevelopment" of Latin American societies was due to a moral, cultural, and physical degeneration caused by the mixing of the "pure" races. De la Cadena shows that while the early indigenistas of the 1920s did believe that hybridity led to moral degeneration because it placed the races outside of their "natural" environment and social milieu, they did not believe that any particular racial origin constitutes a permanent stain of inferiority - rather they argued that any moral or cultural deficiencies of "pure" Indians or mestizos could be remedied through education. In this way they avoided arguing for the racial inferiority of Indians and mestizos (which would have implicated many of themselves as light-skinned mestizos), but were still able to argue for the social and moral inferiority of the "genter del pueblo." For indigenistas, Indians represented a valuable element of their national heritage but one that had been degenerated from its pure and honorable state by their movement out of the indigenous communities. Their brand of indigenismo focused, therefore, on recapturing and recreating the "authentic" culture of the noble Inca, not that of the current "degraded" and "demoralized" Indian. In contrast, another wave of intellectuals of the 1930s, the neo-indianistas, valorized not the pure Indian but rather the hybridized popular culture of the "cholo mestizo" as a source of national identity. Whether arguing for the natural and necessary separation of the "pure" Indians in their rural villages as indigenistas did or celebrating the hybrid culture of the urban mestizo as neo-indianistas did, cuzqueño intellectuals always maintained a distance between themselves as students and representers of indigenous or "cholo mestizo" culture and the working class cuzqueños from whom this culture emanated through a racialized class discourse which marked them as the natural carriers of "decency." As de la Cadena convincingly argues, it was this discourse of decency that allowed elites to avoid the language of biological race while maintaining social hierarchies. De la Cadena's analysis of these elite formulations is replete with historical detail and pays close attention to the variations that existed among them due to their historical era, personal histories, and relation to the hegemonic ideologies of race and place in Peru - all details that show the peculiarities of intellectual thought in Cuzco due to its location in the highlands and former seat of the Inca empire.

Aside from the thorough investigation of elite representations of mestizaje and indigenismo, what makes de la Cadena's work an especially valuable contribution to the literature on race in Latin America is that she also discusses the way that these ideologies have been both appropriated and reformulated by the cuzqueño working 
Reviews

class; that is, how the discourses of mestizaje and indigenismo operate "on the ground." In contrast to elite and anthropological formulations of mestizaje, working class cuzqueños do not understand the process of becoming a mestizo as one that necessarily entails miscegenation nor a permanent unilinear loss of indigenous culture. In fact she shows that "mestizo" and "Indian" are not fixed identities but rather are relational and contextual - one can be mestizo in one context and Indian in another; one can be mestizo (as a social condition, i.e., urban and literate) but with indigenous cultural traits. Thus for these "indigenous mestizos" being Indian or mestizo is not about blood nor about unilinear acculturation, but rather about improving one's social conditions. Through a process that she calls "de-Indianization" grassroots intellectuals distance themselves from the negative connotation of Indianness by not self-identifying as such and yet proudly exhibit indigenous culture. Using Gramsci's notion of contradictory consciousness, de la Cadena points out that while this redefines Indianness as a social condition, rather than as an immutable, biological essence, the fact that the social conditions of Indianness are still associated with the bottom of the social hierarchy continues to leave room for racism to persist and be reproduced.

One of the more interesting conclusions that she draws from her material is what the implications that this process of de-Indianization has for understanding the relative absence of social movements in Peru that are explicitly articulated around an indigenous ethnic identity. She argues that this absence can be explained by the effects of the hegemonic assumption originating with the indigenistas that an educated and political savvy Indian is really a mestizo, and therefore any political movement among Indians is either inauthentic or irrationally motivated. Through this ideology of Indianness, indigenous political movements, at least through the 1980s, have been discredited and/or redefined as purely economic rather than socio-cultural struggles. Though the consequences of this discourse might be particular to Peru (in contrast to many other parts of Latin America where ethnic social movements are very conspicuous), de la Cadena's analysis of the process through which indigenous identity has been muted has implications for understanding the discursive struggles of many different indigenous social movements throughout Latin America.

In general de la Cadena offers an insightful, complex, and multilayered analysis of the workings of race in Cuzco, Peru. Throughout the text she shows multiple subject positions among elite and the working class. Her analysis is always gendered and pays close attention to detail. In spite of the length and detail of the book, however, I was still left with the feeling that more of the voices of de la Cadena's informants could have been brought to the fore. She states in the introductory chapter that she spent hours talking with market women and she includes a wealth of detail about the organization and functioning of mayordomías and comparsas (dance troupes) with whom she conducted participant observation. And yet her analysis of racial discourses mainly revolves around intellectual writings, oral histories, and folklore performances, rather than the details of how terms and discourses are used in day-to-day life. Her argument that "indigenous mestizos" have redefined the terms "mestizo" and "Indian" to refer only to social conditions and not to biology would have been even more convincing had she included at least some consideration of the way that race is articulated to notions of kinship and descent. As other scholars of mestizaje have shown, kinship, marriage and reproduction are often the sites where racialized discourses emerge most forcefully even when other arenas of social life can be glossed as culture or class.

Nonetheless I highly recommend this book for students of race in Latin America. It is theoretically sophisticated, rich in detail, and adds a much needed analysis of how mestizaje is understood from the point of view of those Peruvians whose identity fluctuates between mestizo and indigenous. In the end, de la Cadena's analysis lays an important foundation for understanding the historical, intellectual, and social origins of current popular social movements in Peru. 